\title{
Greywater as an Alternative Solution for a Sustainable Management of Water Resources-A Review
}

\author{
Hanen Filali ${ }^{1,2, *}$ (), Narcis Barsan ${ }^{3, *}$, Dalila Souguir ${ }^{1}$ (), Valentin Nedeff ${ }^{3,4}$, Claudia Tomozei $^{3}$ \\ and Mohamed Hachicha ${ }^{1}$ \\ 1 National Research Institute of Rural Engineering, Water and Forests, University of Carthage, 17 rue Hédi \\ Karray, BP no. 10, Ariana 2080, Tunisia; Souguir_2004@yahoo.fr (D.S.); hachicha08@gmail.com (M.H.) \\ 2 Faculty of Sciences of Bizerte, University of Carthage, Jarzouna, Bizerte 7021, Tunisia \\ 3 Faculty of Engineering, Vasile Alexandri University of Bacau, Calea Marasesti, no. 157, \\ 600115 Bacau, Romania; vnedeff@ub.ro (V.N.); claudia.tomozei@ub.ro (C.T.) \\ 4 Gheorghe Ionescu Sisesti, Academy of Agricultural and Forestry Sciences, 6 Marasti Blvd., \\ 011464 Bucharest, Romania \\ * Correspondence: hanenfilali.26@gmail.com (H.F.); narcis.barsan@ub.ro (N.B.)
}

check for updates

Citation: Filali, H.; Barsan, N.; Souguir, D.; Nedeff, V.; Tomozei, C.; Hachicha, M. Greywater as an Alternative Solution for a Sustainable Management of Water Resources-A Review. Sustainability 2022, 14, 665. https://doi.org/10.3390/su14020665

Academic Editor: Mike Spiliotis

Received: 6 December 2021

Accepted: 4 January 2022

Published: 7 January 2022

Publisher's Note: MDPI stays neutral with regard to jurisdictional claims in published maps and institutional affiliations.

Copyright: (C) 2022 by the authors. Licensee MDPI, Basel, Switzerland. This article is an open access article distributed under the terms and conditions of the Creative Commons Attribution (CC BY) license (https:// creativecommons.org/licenses/by/ $4.0 /)$.

\begin{abstract}
In this paper, a comprehensive review on greywater is presented. Emphasis is given to the techniques used to treat and recover greywater, and special emphasis is placed on the risk of the existence of the novel coronavirus "SARS-CoV-2" in greywater and the possibility of its spread via the reuse of this water. In general, greywater is considered wastewater collected from domestic sources, with the exclusion of toilet water (which is considered as blackwater). Greywater represents $50 \%$ to $80 \%$ of the total volume of wastewater all over the world. This review provides various aspects related to greywater, such as origins, characteristics, and existing guidelines for greywater proper treatment and reuse. Several approaches and techniques have been developed to study the performance of different greywater treatment systems. These methods are critically discussed in this article. In the context of sustainable development, water management, and taking into account the scarcity of water resources, particularly in arid and semi-arid areas, the use of treated greywater is one of the alternatives methods that can reduce the burden of withdrawals from the resource. In addition, some successful examples of greywater valuation experiences in Tunisia were examined.
\end{abstract}

Keywords: greywater; sustainable management; reuse; COVID-19 pandemic; SARS-CoV-2 risk

\section{Introduction}

Demographic growth in a context marked by urbanization and economic development exerts an accentuated strain on conventional water resources in the world. increased attention to alternative water resources has become necessary, especially in semi-arid and arid regions, where the scarcity and variability of rainfall and high evaporation affect the water and salt balance in the soil [1].

Water scarcity is currently one of the most important challenges for human health and the integrity of the environment in most regions of the world and especially in Tunisia. The uneven distribution of precipitation and the temperatures in these countries are the key factors of an imbalance between water supply and demand [2]. Tunisia will suffer from a physical water shortage (high indicator $>1$ ), which will cause a deficit in cereal production [3]. The availability of surface-water resources in Tunisia is medium in the long term. According to statistics published by the Ministry of the Environment and Sustainable Development, Tunisia's water potential increased by $19 \%$ from 1980 to 2005 . The rate of exploitation of the surface water mobilized is approximately $25 \%$. The groundwater exploitation rate is $108 \%$ for water tables and $81 \%$ for deep water tables. The rate of exploitation of available water resources is $51 \%$. The annual quota per inhabitant is $480 \mathrm{~m}^{3}$ /year/inhabitant, below the poverty line $\left(1000 \mathrm{~m}^{3} /\right.$ year/inhabitant $)$ and fairly close 
to the scarcity threshold ( $500 \mathrm{~m}^{3} /$ year/inhabitant). Tunisia will be among the countries that will import more than $10 \%$ of their cereal consumption in 2025 . Therefore, this situation forces us to search some alternate water sources. In this regard, the use of treated greywater can play a significant role in the water demands and development of the sustainable water-resource management [4].

Greywater is the domestic wastewater from showers, hand-washing basins, laundry, washing machines, and kitchen sewage, excluding toilet wastes and food wastes derived from garbage grinders, which are considered blackwater [5]. Greywater contribution to domestic wastewater is $50-80 \%$ of the water volume and includes $18-22 \%, 20-32 \%$, and $9-14 \%$ of potassium $(\mathrm{K})$, phosphorus $(\mathrm{P})$, and nitrogen $(\mathrm{N})$, respectively, so it can be reused after a simple treatment [6].

The exploitation of treated greywater includes indoor reuse, such as flushing toilets, and outdoor reuse, such as irrigation and vehicle washing [7]. Recycling capacity was developed in agriculture whenever the treated greywater conforms to different health and environmental standards established for this purpose [8].

Given the numerous problems of the water-resource scarcity, an effective method of using alternative resources is the greywater reprocessing and its reuse, especially in the agriculture sector. According to the National Sanitation Utility (ONAS 2018), the reuse of treated water for irrigation is a strategic choice that aims to preserve Tunisia's limited water resources, because this sector is the largest consumer of water, at $80 \%$. TWW derived from 122 of Tunisia's wastewater treatment plants, which are located close to the cities, and the secondary treatment is used in most of this sector, as it is the largest consumer of water, at $80 \%$. The reuse of greywater recycled in agriculture can be beneficial for the environment, because it reduces the load on the source and the discharge of wastewater in ecosystems [9]. The nutrients contained in these waters, mainly $\mathrm{N}$ and $\mathrm{P}$, can improve plant growth, instead of polluting the aquatic environment, and requires only some simple treatment operations through less expensive processes. These nutrients originate from detergents and chemicals used in kitchens, dishwashers, or washing machines [10]. In many regions of the world, particularly where the water sources are unavailable, the economic incentive to reuse is substantial. For example, in countries such as Kuwait, Italy, Spain, Malta, Germany, Jordan, or USA, treated greywater is already used for irrigation [11]. It is estimated that 20 million farmers worldwide use untreated or partially treated wastewater [12]. However, in the current context of the COVID-19 pandemic caused by a new type of severe acute respiratory syndrome coronavirus (SARS-CoV-2), the reuse of greywater is facing new challenges brought by the pandemic, especially since traces of this SARS-CoV-2 virus have been found in the wastewater of several countries around the world [13-15]. This raises the question of the effects and risks on the environment and public health.

The objective of this paper was to review some agricultural valorization of greywater through success experiences, as well as considering the various treatment processes from Tunisia and assessing the impact to preserve freshwater and protect the environment.

\section{Origin and Characteristics of Greywater}

Greywater is defined as wastewater without any blackwater discharge, and it corresponds to a large volume of wastewater with a high potential for reuse and application. Greywater's origin and composition depend on the lifestyle, population structure, availability of water, and climatic conditions, which are different from one country to another [16]. Greywater quantities vary from 90 to 120 lpd in houses with water supply system. This range corresponds with that determined by Mandal et al. (2011) [17]. In fact, greywater average is 110 lpd: 80 lpd from bathing, cloth washing, and wash basins; and 30 lpd from kitchen greywater. Greywater consists of a wide range of organic materials [18], heavy metals [19-22], and E. coli [22].

The characteristics of greywater depend essentially on the quality of water used for the initial supply. In addition, the type of habitat, the number and the sanitary state of the occupants, the source and volumes of water collected, the treatments used, and the 
storage conditions can influence the greywater characteristics. These elements vary for each country, considering the differences in climate and demography. Temporal variations in greywater in the same area may be due to a change in the behavior of the inhabitant or to a specific use of a product [23].

Before thinking of recycling greywater, the first step is to characterize its chemical, physical, biological, and microbiological properties [24]. Because there is no specific standard for greywater use, the general quality can be compared with standards used for treated wastewater quality. The $\mathrm{pH}$ is slightly alkaline for greywater from washing machines and, to a lesser extent, for greywater from bathrooms. Total suspended solids (TSSs) and turbidity in greywater are heterogeneous: water that comes from bathrooms has lower TSS concentrations than that from washing machine. The concentrations of biological oxygen demand (BOD), chemical oxygen demand (COD), and nutrients (nitrate (N) and phosphorus (P)) are higher in the laundry-washing water. This difference observed is due to detergents containing carbon and phosphate products, especially in countries where their use is not yet banned [25].

For heavy metals and organic pollutants in greywater, they are generally low in different types of greywater. The work carried out by Filali et al. in 2017 [10] showed that the different heavy metals $(\mathrm{Co}, \mathrm{Cr}, \mathrm{Cu}, \mathrm{Fe}, \mathrm{Mn}, \mathrm{Ni}, \mathrm{Pb}$, and $\mathrm{Zn}$ ) analyzed in the greywater of kitchens and bathrooms are low and below the limit. For microbiological parameters, the characteristics of the two types of water are equivalent. In general, greywater from bathrooms contains elements brought by human activity (hair, skin, shampoos, and solvents). Greywater from washing machines mainly contains detergents and textile fibers, but sometimes it contains organic matter provided by the dirt on clothes [20].

\section{Risks Related to the Greywater Reuse}

The chemical and microbiological hazards in untreated and treated greywater are variable because these qualities depend on human behavior and the materials discharged into greywater. Given the small number of publications identified and the diversity of greywater reuse situations, the available data only provide some indication related to the chemical and microbiological composition of greywater, but they cannot be considered as being representative of the chemical contamination and microbiological of all greywater. Untreated greywater from households contains a high concentration of compounds with harmful effects on all of the environment [26]. Faulwetter et al. (2009) [27] determined that the microbial activity of the soil can be affected by the untreated greywater used for plants' growth; long-term irrigation with greywater can also increase the alkalinity of the soil, the rate of sodium adsorption, and electrical conductivity $[10,28]$.

\subsection{Environmental Risks}

One of the main environmental risks resulting from the reuse of greywater is groundwater pollution. It is possible that some of the substances found in greywater influence the groundwater supplies [29,30]. Sanae Kholtei et al. (2007) [31] have highlighted several determining factors [31] in the contamination of groundwater by greywater pollutants: the supply of nitrogen fertilizers, the nature of the soil, the lithology, and the permeability of the aquifer. To reduce the impact of greywater reuse on groundwater, the potential user must analyze and study the nutrient requirements by plants and soil. Wiel-Shafran et al. (2006) [12] suggested that the accumulation of surfactants in the soil due to greywater irrigation can create water-repellent soils, thus affecting their flow profiles and productivity. In a study conducted by Al-Hamaiedeh and Bino (2010) [11] to assess the effect of the treated greywater reuse on the soil properties and irrigated plants, the results exhibited increases in the soil salinity and organic matter contents. The chemical properties of irrigated olive trees and vegetable crops were not affected, while the organic quality of some vegetable crops was negatively affected. The main effects of greywater on the soil are linked to (i) the increase in the hardness and salinity of the soil; (ii) the reduction of the capacity of the soil 
to absorb and retain water; and (iii) the increase in alkalinity, due to the presence of sodium, potassium, or calcium salts in greywater, in particular, in detergents (OMS, 2006).

\subsection{Sanitary Risks}

Epidemiological studies and microbiological analyses are necessary to evaluate the health risks associated with greywater. These risks depend on the treatment applied, the routes of exposure, and the source of the pathogens [32]. Ottoson and Stenstrom (2003) [33] showed that the prevalence of pathogens has served as the basis for a quantitative evaluation of the microbial risk at the screening level that has been undertaken for rotavirus, Salmonella typhimurium, Campylobacter jejuni, Giardia lamblia and Cryptosporidium parvum. The different scenarios of direct exposure, irrigation of sports fields, and recharge of groundwater have shown unacceptable risks of rotavirus despite a low fecal load. The quantitative microbial risk assessment (QMRA) methods have shown that the growth conditions of Salmonella in sediments increased the probability of infection by 1000 times, but it was even lower than the risk of rotavirus infection.

Other greywater studies elaborated by Rodda et al. (2011) [8] have detected the effect of greywater on crop irrigation, Beta vulgaris variety Cicla and a carrot crop, Daucus carota. The results indicated that soils irrigated with greywater showed a risk of salinity and sodicity increasing, coupled with high concentrations of heavy metals.

The pathogenic and non-pathogenic microorganisms present in greywater are of the same nature as those found in domestic wastewater [32]. In addition, certain pathogens can multiply due to the composition of greywater. These waters contain low levels of fecal contamination, provided that it is strictly separated from blackwater. These pathogens can be ingested, leading to gastroenteric disorders; can be inhaled as water droplets or aerosols responsible for respiratory infections; or cause infections of the skin or healthy or damaged mucous membranes [34].

Some substances produced by bacteria could also constitute a risk, such as endotoxins, the health impact of which is still little studied. Maimon et al. (2010) [9] determined the presence of various pathogens in the digestive system.

\section{- $\quad$ Risk of SARS-CoV-2 transmission through greywater}

Despite the disinfection practices followed by users of recycled water [35], the real health risk remains linked to microbial and/or viral contamination. This leads us to reflect on the consequences of COVID-19 epidemic, as well as the impact of SARS-CoV-2 virus on the composition of greywater, which can worsen the health risk associated with the reuse of this water. Indeed, several studies have identified a great similarity (up to 82\%) [36,37] of this virus with that of SARS-CoV-1, which appeared in 2003 [13]. This one has shown its ability to spread in sanitation systems [38]. Several studies have suggested that SARSCoV-1 infection was caused by breathing in aerosols created in faulty plumbing systems and toilet flushes [39]. Therefore, wastewater has been defined as a route of indirect contamination with SARS-CoV-1 [40]. For the new virus responsible for the COVID-19 epidemic, intensive studies have shown that SARS-CoV-2 can enter sanitation systems via human excretions, such as stool, urine, saliva, etc. [13,41,42], and the spread of the virus via the fecal/oral route has become highly probable $[15,43]$. Indeed, gastrointestinal disturbances were considered among the key symptoms of SARS-CoV-2 infection, where $80 \%$ of patients affected by COVID-19 had diarrhea, constipation, and vomiting [15,42]. Studies have confirmed the detection of SARS-CoV-2 RNA in $66.67 \%$ of stool samples from patients with gastrointestinal symptoms [15]. In addition, it is not only for these patients, but SARS-CoV-2 RNA shedding was observed also in asymptomatic patients [15]. SARS-CoV-2 RNA has been found in stool samples even after recovery from respiratory infection [44]. Other works have shown that the SARS-CoV-2 virus has been found in wastewater from several countries, such as the United States, Sweden, The Netherlands, Israel, etc. $[13,14,45-47]$. This means that even greywater from areas where COVID-19 patients are located could be a potential source for the virus to spread, as well as its transmission. Contamination of greywater with SARS-CoV-2 is a significant concern, as 
it can threaten human and environmental health, especially in countries that allow the use of greywater without any treatment, as in Bangladesh, Pakistan, and Iran [48-50], where irrigation with untreated wastewater is a common practice in urban, peri-urban, and gardens areas. Moreover, in comparison with wastewater, we can say that greywater is more likely to spread the coronavirus, due to the simple treatment it undergoes on the one hand, and the large quantity produced of greywater during the COVID-19 pandemic on the other hand. Indeed, one of the best ways to prevent and break the chain of infection of COVID-19 is to wash hands with soap and water several times during the day [51]. This requirement increases the production of greywater.

\section{Greywater Recovery Systems}

The characterization of greywater and its comparison with domestic wastewater have shown the advantage of recycling this water category. Greywater recycling processes are, in general, based on the conventional processes for domestic, urban, and industrial wastewater treatment [52]. Thus, as in the field of wastewater treatment, greywater treatment systems most often constitute a treatment sector. Generally, the physical (sand filters, activated carbon filters, membrane filters, etc.), chemical (coagulation, ion exchange, chlorination, etc.), and biological (filtering marshes, RBC, SBR, and sludge blanket) treatment processes of greywater are preceded by pretreatment (sieving, decantation) to reduce the rates of particulate load of oils and greases and functioning as a basin of regulation/homogenization of the flow of the load of pollution of untreated greywater [53-55]. Several studies relating to alternatives and methods for recovering treated greywater have been evaluated according to the characteristics of greywater, their standardization, directives, and recommendations in force. Overall, all types of greywater have shown a good biodegradability. Greywater from bathrooms and washing machines is deficient in nitrogen and phosphorus, while greywater from kitchens has a balanced N:P ratio. These researches also showed that the physical greywater treatment processes are not sufficient. To ensure adequate reduction of organic matter, nutrients, and surfactants, a chemical process can effectively reduce suspended solids, organic matter, and surfactants from greywater. The combination of aerobic biological processes with physical filtration and disinfection has been considered as the most economical and practical solution for recycling greywater from collective urban residential buildings [53]. The selection of a greywater recovery-type process, as well as its dimensioning, depends on the flows and the composition of greywater to be treated, the application process scope, and the quality of treated greywater required by applicable regulations, guidelines, and standards [56].

\subsection{Physical Systems}

These treatment methods are most often used in combination with another method, such as disinfection and adsorption on activated carbon. The sand filter is a simple technology, easy to implement, and inexpensive. Some authors use, in addition to or instead of sand, other materials, such as activated carbon. These authors have shown the limits of the performance of sand filters in the recovery of greywater. This physical process only provides coarse filtration and allows limited treatment. Gual et al. (2008) [57] obtained between $15 \%$ and $25 \%$ elimination of TSS and COD from greywater. A study by Itayama et al. (2006) [58] showed that $\mathrm{BOD}_{5}, \mathrm{COD}, \mathrm{TSS}$, and total nitrogen (TN) values of greywater from kitchen sinks were reduced from $477 \mathrm{mg} / \mathrm{L}, 271 \mathrm{mg} / \mathrm{L}, 105 \mathrm{mg} / \mathrm{L}$, and $20.7 \mathrm{mg} / \mathrm{L}$ to $81 \mathrm{mg} / \mathrm{L}, 40.6 \mathrm{mg} / \mathrm{L}, 23 \mathrm{mg} / \mathrm{L}$, and $4.4 \mathrm{mg} / \mathrm{L}$, respectively, by a soil filtration system. This greywater treatment system is capable of partially removing organics and particulate pollutants, as well as nitrogen and phosphorus nutrients. The quality of the treated greywater obtained by Gual et al. (2008) [57] has shown that organic material and suspended matter remains high, and this can limit the chemical disinfection process [6]. Dalahmeh et al. (2012) [59] found that the best performance of greywater treatment with an active carbon filter was able to achieve $98 \%, 97 \%$, and $94 \%$, respectively, for the reduction of total nitrogen, $\mathrm{BOD}_{5}$, and COD. Mandal et al. (2011) [17] achieved a reduction of $1 \log 10$ 
in total coliforms by a sponge and gravel filter system. Brewer et al. (2001) [60] achieved a reduction of $4 \log 10$ in total coliforms by a filtration system followed by disinfection.

Sand filtration combined with activated carbon adsorption and disinfection has been reported for the treatment of greywater. Pidou et al. (2007) [61] revealed some improvement in the reduction of suspended solids and turbidity. However, a reduction in microbial load is limited. The dissimilarities observed in the various studies can be explained by the characteristics of the greywater specific to a dwelling or by the characteristics of filter used (applied load, filtration speed, properties of the filtering materials, etc.). In order, to limit environmental and health risks, Diaper et al. (2001) [62] recommended the use of greywater, after treatments, only for toilets, because of the uncertainties on risk outcomes. Francis W. et al. (2012) [63] confirmed that the use of greywater from the bathroom and linen is safe for flushing toilets and irrigating food crops after microfiltration treatment.

If we consider the greywater reuse for green-spaces irrigation, typically it is necessary to choose an advanced treatment that makes it possible to obtain a better-quality effluent. For example, membrane-filtration techniques applied to the recovery of greywater have been much studied in recent years. Ramon et al. (2004) [22] compared the purifying performance of ultrafiltration and nano-filtration membranes. With ultra-filtration, only $49 \%$ and $94 \%$ of reduction were obtained for COD and turbidity, while $93 \%$ and $98 \%$ were obtained with nano-filtration.

Sostar-Turk et al. (2005) [64] studied the purifying performance of an ultrafiltration membrane $(0.05 \mu \mathrm{m}$ pore size) for the treatment of greywater. This ultrafiltration process allowed for a reduction in $\mathrm{BOD}_{5}$ from 195 to $86 \mathrm{mg} / \mathrm{L}(56 \%)$, values that do not ensure the standard limits for greywater reuse. According to Pearce (2007) [65], this technology makes it possible to obtain water with acceptable quality. In fact, the almost-total retention of molecules makes it possible to obtain a quality permeate which complies with most of the regulations in force for the reuse of treated greywater

\subsection{Chemical Systems}

The chemical processes applied to greywater treatment include coagulation, electrocoagulation, photo-catalytic oxidation, disinfection, etc. These main chemical processes seem to be relatively effective for the recovery of greywater. Several studies have shown significant reductions in organic load (COD and $\left.\mathrm{BOD}_{5}\right)$. Lin et al. (2005) [66] studied the performance of electrocoagulation, followed by a disinfection step, for the recovery of greywater. The values of COD, $\mathrm{BOD}_{5}$, turbidity, and TSS in greywater decreased from $55 \mathrm{mg} / \mathrm{L}$, $23 \mathrm{mg} / \mathrm{L}, 43 \mathrm{NTU}$ and $29 \mathrm{mg} / \mathrm{L}$ to $22 \mathrm{mg} / \mathrm{L}, 9 \mathrm{mg} / \mathrm{L}, 4 \mathrm{NTU}$ and $9 \mathrm{mg} / \mathrm{L}$, respectively.

For the microbiological parameters, Lin et al. (2005) [66] did not detect E. coli bacteria in greywater. Moreover, Bani-Melhem and Smith (2012) [67] obtained reductions of $4 \log 10$ for total coliforms and E. coli by using an electrocoagulation system coupled to a membrane bioreactor. In a study conducted by Pidou et al. (2007) [61], the coagulation and ionexchange resin processes were applied for the recovery of greywater from showers.

Under optimal conditions, coagulation with aluminum salt reduces COD from 791 to $287 \mathrm{mg} / \mathrm{L}, \mathrm{BOD}_{5}$ from 205 to $23 \mathrm{mg} / \mathrm{L}$, turbidity from 46.6 to $4.28 \mathrm{NTU}$, TN from 18 to $15.7 \mathrm{mg} / \mathrm{L}$, and orthophosphates from 1.66 to $0.09 \mathrm{mg} / \mathrm{L}$. In addition, total coliforms, E. coli, and fecal enterococci in the greywater recovered are all less than $1 \mathrm{CFU} / 100 \mathrm{~mL}$. These researchers have also shown that it is possible to reduce $\mathrm{BOD}_{5}$, turbidity, total nitrogen, and orthophosphates to $33 \mathrm{mg} / \mathrm{L}, 8.14 \mathrm{NTU}, 15.3 \mathrm{mg} / \mathrm{L}$ and $0.91 \mathrm{mg} / \mathrm{L}$, respectively, by using ion-exchange resins in their treatment process. The total coliforms and E. coli in the greywater recovered were $59 \mathrm{CFU} / 100 \mathrm{~mL}$ and $8 \mathrm{CFU} / 100 \mathrm{~mL}$, respectively. An advanced oxidation process based on photo-catalytic oxidation with the combination of titanium dioxide and UV for the treatment of greywater has shown its proof in the removal of $90 \%$ from organic matter and $6 \log 10$ in the reduction of total coliforms [68]. 


\subsection{Biological Systems}

Biological processes are the most common large-scale treatments used to treat greywater. These processes can operate aerobically, anaerobically, or in a combined process. Some studies present different results related to the performance of biological processes with suspended and fixed biomass, and in the case of biofilters' use for greywater recovery. Otterpohl et al. (1999) [69] recommended the use of fixed biomass processes rather than suspended biomass processes, considering the process complexity and the used space. Furthermore, the use of a fixed biomass process makes it possible to increase the total biomass in the reactor and consequently improve the performance of the treatment [70].

A study by Elmitwall et al. (2007) [71] showed a reduction in COD, total, total nitrogen (TN), and total phosphorus (TP), respectively reaching 31\%, 24\%, and $39 \%$ with a sludge bed. Baban et al. (2010) [42] reported reductions of $94 \%$ for TSS, $86 \% \mathrm{BOD}_{5}, 95 \%$ COD $88 \%$ NT, $71 \%$ for PTP, and $100 \%$ for turbidity by using a sequenced batch reactor (RBC SBR) biological process. Regarding the microbiological part, the reduction in total coliforms by this biological process was only $1 \log 10$. It is therefore useful to add a disinfection treatment to reduce the microbial load. Lamine et al. (2007) [72] evaluated the performance of a sequenced batch reactor (SBR) for the treatment of greywater. The results found reductions of $30 \% \mathrm{TSS}, 93 \% \mathrm{BOD}_{5}, 88 \% \mathrm{COD}$, and $96 \%$ respectively in turbidity of greywater.

The recovery of greywater via a membrane bioreactor (MBR) was also considered as an innovative technology, given the stability of the process and its potential to eliminate pathogens. Lin et al. (2005) [66] reported that the values of $\mathrm{COD}, \mathrm{BOD}_{5}$, and anionic surfactants were decreased from 322 to $18 \mathrm{mg} / \mathrm{L}$, from 221 to less than $5 \mathrm{mg} / \mathrm{L}$, and from 8 or $9 \mathrm{mg} / \mathrm{L}$ to less than $0.5 \mathrm{mg} / \mathrm{L}$ on average in the permeate. Other research [71] showed that the upflow anaerobic sludge blanket (biological process UASB) allowed a reduction from $31 \%$ to $41 \%$ of the total COD, from 24 to $36 \%$ of the TN, and from 10 to $24 \%$ of TP.

The biological filter processes have been considered the most environmentally friendly, low-cost, and effective treatments for greywater. The studies from the literature related to the use of biological filter have shown interesting performances, particularly in terms of $\mathrm{BOD}_{5}$, TSS, and turbidity elimination. Gross et al. (2007) [73] observed more than $89 \%$ and $96 \%$ reduction, respectively, for TSS and $\mathrm{BOD}_{5}$. From a microbiological point of view, Dallas et al. (2004) [74] found that it is possible to reduce the load of total coliforms at $6 \log 10$, while Travis et al. (2010) [26] were able to reduce this same load only at $3 \log 10$. Regarding maintenance, these filter processes require little maintenance and therefore have a low operating cost. Plant maintenance must be carried out by cutting, as well as cleaning, every 5 to 10 years in order to remove the sludge accumulated at the bottom of the lagoon [75]. Moreover, these processes have the advantage of being integrated into the landscape and contribute to the fauna and flora diversification.

\subsection{Hybrid Systems}

Other hybrid processes considered as innovative technologies, such as membrane bioreactors alone or associated with membrane filtration (nanofiltration (NF) or ultrafiltration (UF)), or aerated biofilter processes alone or associated with filter marshes, have been tested for greywater recovery. The overall performance of these processes is very satisfactory, because the coupling of the two processes ensures both physicochemical and microbiological purification. Some research showed important reductions greater than $95 \%, 75 \%, 93 \%$, and $85 \%$ for turbidity, TSS, $\mathrm{BOD}_{5}$, and COD $[53,67,76]$. Concerning the surfactants, the reductions obtained by the BRM/UF processes and by the aerated biofilter processes are greater than $95 \%$. Only total phosphorus appears to be difficult to reduce. The reduction of phosphorus by the BRM/NF processes and by the aerated biofilter processes coupled to the filter marshes was, respectively, $31 \%$ and $61 \%$. At the microbiological level, these hybrid processes (BRM/UF) seem to be efficient, with the regular reduction of fecal coliforms of $4 \log 10$ [67,77]. At the expense of improving the quality of greywater through hybrid physical and biological processes, there is also a significant increase in the production cost of treated greywater. 


\section{Existing Regulations for Greywater}

The reuse of treated wastewater has experienced tremendous global growth. Today, treated wastewater is considered in many countries, and particularly in Tunisia, as an important new resource with many interests, both from an environmental and economic standpoint. The development of the treated wastewater reuse is encouraged in Tunisia, despite the challenges and constraints related to various aspects (legislative, health, economic, environmental, agronomic, technological, etc.). Several international organizations in charge of regulation have made it possible to identify regulations, guidelines, and recommendations, as well as international standards, relating to the reuse of treated wastewater for various agricultural, urban, and domestic uses. Table 1 presents the regulations and standards identified in Tunisia and abroad, relating to the reuse of treated wastewater, in general, and greywater, in particular. The physicochemical and microbiological quality criteria of wastewater or treated greywater have been defined by certain states within the framework of regulations or recommendations for reuse. These water-quality criteria, as well as the threshold values for reuse defined by some developed countries (Australia, Germany, Japan, and United Kingdom) and by other countries (Spain, Jordan, and Tunisia), were mainly interested in agricultural utilization, and urban and domestic irrigation. Other countries have established limit values for other types of reuse, such as fire protection, vehicles washing, and possible toilet uses. In Tunisia, greywater does not have specific standards for reuse, it is included with all the wastewaters sent to treatment stations. Therefore, the standard adopted in Tunisia refers to the reuse of treated wastewater processed for agricultural purposes (NT 106-.03) (INNORPI, 1989). Water quality is monitored by physicochemical and biological indicators of wastewater pollution $\left(\mathrm{pH}, \mathrm{COD}, \mathrm{BOD}_{5}, \mathrm{TSS}\right.$, turbidity, etc.) and microbiological contamination indicators (CT, CF, E. coli, Enterococci, and Legionella), as well as and parasitic (protozoan) indicators.

Table 1. Regulations and standards identified in Tunisia and abroad relating to the reuse of treated wastewater in general and greywater in particular.

\begin{tabular}{|c|c|c|c|c|c|c|c|}
\hline \multirow{2}{*}{$\begin{array}{c}\text { Countries } \\
\text { Types of } \\
\text { Water }\end{array}$} & \multirow{2}{*}{$\begin{array}{c}\text { Australia } \\
\text { Treated } \\
\text { Greywater }\end{array}$} & \multirow{2}{*}{$\begin{array}{c}\text { Jordan } \\
\text { Treated } \\
\text { Wastewater }\end{array}$} & \multicolumn{4}{|c|}{ Spain } & \multirow{2}{*}{$\begin{array}{c}\text { Tunisia } \\
\text { Treated } \\
\text { Wastewater }\end{array}$} \\
\hline & & & \multicolumn{4}{|c|}{ Treated Wastewater } & \\
\hline Use & $\begin{array}{l}\text { Domestic } \\
\text { irrigation }\end{array}$ & $\begin{array}{l}\text { Agricultural } \\
\text { irrigation }\end{array}$ & $\begin{array}{l}\text { Agricultural } \\
\text { irrigation }\end{array}$ & $\begin{array}{l}\text { Domestic } \\
\text { irrigation }\end{array}$ & Fire protection & Vehicle washing & $\begin{array}{l}\text { Agricultural } \\
\text { irrigation }\end{array}$ \\
\hline $\mathrm{EC}$ & ND & ND & ND & ND & ND & ND & ND \\
\hline $\mathrm{pH}$ & ND & $6.5-9$ & ND & ND & ND & ND & $6.5-8.5$ \\
\hline $\mathrm{DBO}_{5}$ & $<10 \mathrm{mg} \mathrm{O}_{2} \mathrm{~L}$ & $<30 \mathrm{mgO}_{2} \mathrm{~L}$ & ND & ND & ND & ND & $<30 \mathrm{mgO}_{2} \mathrm{~L}$ \\
\hline COD & ND & $<100 \mathrm{mgO}_{2} \mathrm{~L}$ & ND & ND & ND & ND & $<90 \mathrm{mgO}_{2} \mathrm{~L}$ \\
\hline TSS & $<10 \mathrm{mg} \mathrm{L}$ & $<50 \mathrm{mg} / \mathrm{L}$ & $35 \mathrm{mg} \mathrm{L}$ & $10 \mathrm{mg} \mathrm{L}$ & $<20 \mathrm{mg} \mathrm{L}$ & $<20 \mathrm{mg} \mathrm{L}$ & $<30 \mathrm{mgO}_{2} \mathrm{~L}$ \\
\hline Bore & ND & ND & ND & ND & ND & ND & $<3 \mathrm{mg} \mathrm{L}$ \\
\hline Fluor & ND & ND & ND & ND & ND & ND & $<3 \mathrm{mg} \mathrm{L}$ \\
\hline Turbidity & ND & ND & ND & $<2 \mathrm{NTU}$ & $<10$ NTU & $<10 \mathrm{NTU}$ & ND \\
\hline E.coli & ND & 100 UFC mL & $<100 \mathrm{UFC} \mathrm{mL}$ & 0 UFC mL & 200 UFC 100 mL & $<200$ UFC $100 \mathrm{~mL}$ & 1000 UFC $100 \mathrm{Ml}$ \\
\hline Helminthes & ND & $<1$ œuf L & ND & ND & ND & ND & $<1$ œuf L \\
\hline Nematodes & ND & ND & 1 œuf.10 L & 1 œuf.10 L & 1 œuf 10 L & 1 œuf 10 L & ND \\
\hline Legionella & ND & ND & 100 UFC L & 100 UFC L & 100 UFC L & 100 UFC L & ND \\
\hline CT & 10 UFC L & ND & ND & ND & ND & ND & ND \\
\hline References & $\begin{array}{c}\text { EPA, } \\
\text { Victoria, } 2013\end{array}$ & $\begin{array}{l}\text { Jordanian } \\
\text { Standards }\end{array}$ & \multicolumn{4}{|c|}{ Ministerio de la presidenci, 2007} & $\begin{array}{c}\text { Tunisian } \\
\text { Standards NT } \\
106,03\end{array}$ \\
\hline
\end{tabular}

\subsection{Guidelines of International Organizations}

To regulate the reuse of wastewater and greywater, some international organizations have relied on health risks. In this review, we focus on the World Health Organization (WHO) [35] and the Food and Agriculture Organization of the United Nations (FAO) [78]

WHO developed guidelines in 1989, revised in 2006 for the use of treated wastewater in agriculture, based on a process of health-risk assessment. These recommendations are based on an analysis of health risks for domestic uses (watering gardens, flushing toilets, 
and washing cars). However, secondary treatment of treated greywater with disinfection is recommended. The development of a local management plan for the use of treated greywater from buildings and residential facilities is advised. According to WHO [35], $\mathrm{BOD}_{5}, \mathrm{SS}$, and TC are, respectively, $240 \mathrm{mg} \mathrm{O}_{2} \mathrm{~L}^{-1}, 140 \mathrm{mg} \mathrm{L}^{-1}$, and $100 \mathrm{CFU} 100 \mathrm{~mL}^{-1}$ for agricultural irrigation. In the case of fire protection, vehicle washing, and toilet-flush supply, these same parameters are set at $10 \mathrm{mg} \mathrm{O}_{2} \mathrm{~L}^{-1}, 10 \mathrm{mg} \mathrm{L}^{-1}$, and $10 \mathrm{CFU} 100 \mathrm{~mL}^{-1}$.

\subsection{Some Tunisian Experiences of Greywater Treatment}

Greywater constitutes a major part of domestic wastewater. If properly valued and treated, these waters can be a resource for a variety of uses. We tried to evidence some examples of Tunisian experiences that opted for greywater treatment and reuse with successful results.

In a partnership between two teams of Tunisian and German researchers, as a part of a demonstration project, water-saving measures and a dual-piping system concrete example was set up of a local greywater management. This is a study carried out in a community dwelling in Central Berlin, Germany, which consists of three residential buildings that accommodate around 71 families (around 223 inhabitants) [79] in which greywater from showers, bathtubs, sinks, kitchens, and washing machines was advanced physico-biologically treated in a multistage moving-bed biofilm reactor (MBBR), followed by sand filtration and UV disinfection treatment. The treatment system installed in the residential building consisted of nine biological reactors, a sedimentation reactor, and a storage tank, each with a capacity of $1.3 \mathrm{~m}^{3}$. The system was designed to treat 8 to $11 \mathrm{~m}^{3}$ of greywater, depending on the daily water demand. This treated water was reused to flush 90 toilets and to irrigate the gardens. Results of this study showed the high performance of the reactor for the removal of COD, dissolved organic carbon DOC, $\mathrm{BOD}_{5}$, ammonia NH4-N, and TN, with an efficiency of elimination of $93 \%, 80.7 \%$, 90\%, 89\%, and 77\% respectively. In addition, a good correlation was determined between the simulated and experimental concentrations of COD from different reactors of the MBBR system.

As another example of greywater reuse, a study was carried out by Chaabane et al. (2017) [80] to examine the suitability assessment of an upflow-and-downflow siliceous sand/marble filtration system for the treatment and reuse of greywater collected from the bathrooms of the student residential complex of the Medjez El Bab Higher Institute of Engineering (Tunisia). The optimization of a greywater pretreatment system was performed by using a filtration system operated at different hydraulic loading rates and media-filter proportions. By this configuration, the study assessed the suitability of the treated greywater for agricultural purposes according to the risk of salinity, the danger of magnesium, and the permeability index. Moreover, to assess the quality of greywater for industrial reuse, the assessment was made in terms of foaming, corrosion, and scaling. The results showed that the quality of treated greywater by an upflow-downflow siliceous sand/marble filtration system could be accepted for reuse in irrigation. However, the treated greywater was not found to be suitable for industrial use, due to high concentrations of calcium and sodium, which can produce foam and scale in boilers.

Intensified work was unrolled at Center of Researches and Technologies of Waters (CERTE) by Lamine et al. (2007) [72]. This study had two main purposes: to investigate the application of sequencing batch reactors technology (SBR) for the treatment of greywater collected from the student residence shower room and to establish an approach to remove nutrients from greywater in an SBR and the feasibility of this cost-efficient system. The SBR reactor was made up of a transparent Plexiglas cylinder $(19.0 \mathrm{~cm}$ in diameter $)$, with a total volume of $11 \mathrm{~L}$ and a working volume of $5 \mathrm{~L}$. The reactor was equipped with two peristaltic pumps for the supply and discharge. Mechanical stirring (30 rpm) was operated for complete mixing. The results showed that the SBR system could effectively remove nutrients and promote biodegradation of organic matter for domestic greywater up to $90 \%$ COD removal. In addition, the application of two hydraulic retention times (HRTs) 
showed that the removal of nitrogen and phosphorus could be improved while adapting the load variations.

\section{Conclusions}

In recognition of the importance of conserving water resources, considering greywater as an alternative source is essential. This study reviewed the characteristics of greywater from a qualitative and quantitative point of view, as well as the treatment processes, to evidence some possibilities of greywater uses. From the list of reviewed treatment systems, the integration of other complementary systems (such as UV disinfection, reactors, and others) with traditional filtration systems seems to be more efficient for a better water quality. Many countries around the world have established guidelines and standards for the reuse of greywater, but the implementation always remains minimalist, especially in developing countries. The greywater standards summarized in this study can be used to study the effectiveness of new treatments and the potential uses of treated greywater. It is important to understand and assess the risks and dangers associated with the reuse of greywater after the COVID-19 pandemic where the potential of greywater may be a route of transmission of the SARS-CoV-2 virus, which could affect the environment and public health in the case of several countries, such as Tunisia, where the standards intended for the reuse of treated wastewater are applied to assess greywater, with no specific standards for greywater quality. For the cases of some Tunisian experiences of greywater, the techniques used for recycling it are always developed with the aim of eliminating certain specific pollutants and not for a complete treatment. To conclude, we can admit that reusing greywater can be considered both an economically and environmentally friendly solution in the context of water management. A proper greywater-management system can contribute to the conservation of natural resources and the fight against drought. In general, all the aspects related to greywater depends on the public reaction, regulations, and the implementation of proper systems by encouraging households to install greywater treatment systems.

Author Contributions: Conceptualization, H.F. and D.S.; methodology, H.F. and M.H.; validation, M.H.; formal analysis, V.N. and C.T.; investigation, H.F.; writing-original draft preparation, H.F.; writing-review and editing, D.S. and N.B.; supervision, M.H. All authors have read and agreed to the published version of the manuscript.

Funding: This research received no external funding.

Institutional Review Board Statement: Not applicable.

Informed Consent Statement: Not applicable.

Data Availability Statement: Not applicable.

Acknowledgments: The authors thank for the support of the University Agency of La Francophonie (AUF).

Conflicts of Interest: The authors declare no conflict of interest.

\section{References}

1. Hachicha, M. Les sols salés et leur mise en valeur en Tunisie. Sci. Chang. Planét. 2007, 18, 45-50.

2. Santos, C.; Taveira-Pinto, F.; Cheng, C.Y.; Leite, D. Development of an experimental system for greywater reuse. Desalination 2012, 285, 301-305. [CrossRef]

3. Food and Agriculture Organization of the United Nations (FAO). La Situation Mondiale de l'Alimentation et de l'Agriculture. Changement Climatique, Agriculture et Securité Alimentaire. 2016. Available online: https://www.fao.org/3/i6030f/i6030f.pdf (accessed on 15 November 2021).

4. Hyde, K. An evaluation of the theoretical potential and practical opportunity for using recycled greywater for domestic purposes in Ghana. J. Clean. Prod. 2013, 60, 195-200. [CrossRef]

5. Wilderer, P.A. Applying sustainable water management concepts in rural and urban areas: Some thoughts about reasons, means and needs. Water Sci. Technol. 2004, 49, 7-16. [CrossRef]

6. Al-Jayoussi, O. focused environnemental assessement of greywater reuse in Jordan. Environ. Eng. Policy 2002, 3, 67-73. [CrossRef] 
7. do Couto, E.D.A.; Calijuri, M.L.; Assemany, P.P.; da Fonseca Santiago, A.; de Castro Carvalho, I. Greywater production in airports: Qualitative and quantitative assessment. Resour. Conserv. Recycl. 2013, 77, 44-51. [CrossRef]

8. Rodda, N.; Salukazana, L.; Jackson, S.A.F.; Smith, M.T. Use of domestic greywater for small-scale irrigation of food crops: Effects on plants and soil. Phys. Chem. Earth Parts A/B/C 2011, 36, 1051-1062. [CrossRef]

9. Maimon, A.; Gross, A. Greywater: Limitations and perspective. Curr. Opin. Environ. Sci. Health 2018, 2, 1-6. [CrossRef]

10. Filali, H. The use of treated grey water in urban agriculture in Soukra. Arab World Water 2017, 7, 12-13.

11. Al-Hamaiedeh, H.; Bino, M. Effect of treated grey water reuse in irrigation on soil and plants. Desalination 2010, 256, 115-119. [CrossRef]

12. Wiel-Shafran, A.; Ronen, Z.; Weisbrod, N.; Adar, E.; Gross, A. Potential changes in soil properties following irrigation with surfactant-rich greywater. Ecol. Eng. 2006, 26, 348-354. [CrossRef]

13. Medema, G.; Heijnen, L.; Elsinga, G.; Italiaander, R.; Brouwer, A. Presence of SARS-Coronavirus-2 in sewage. Environ. Sci. Technol. Lett. 2020, 7, 511-516. [CrossRef]

14. Sherchan, S.P.; Shahin, S.; Ward, L.M.; Tandukar, S.; Aw, T.G.; Schmitz, B.; Ahmed, W.; Kitajima, M. First detection of SARS-CoV-2 RNA in wastewater in North America: A study in Louisiana, USA. Sci. Total Environ. 2020, 743, 140621. [CrossRef] [PubMed]

15. Chen, Y.; Chen, L.; Deng, Q.; Zhang, G.; Wu, K.; Ni, L.; Yang, Y.; Liu, B.; Wang, W.; Wei, C.; et al. The presence of SARS-CoV-2 RNA in the feces of COVID-19 patients. J. Med. Virol. 2020, 92, 833-840. [CrossRef]

16. Oteng-Peprah, M.; Acheampong, M.A.; DeVries, N.K. Greywater Characteristics, Treatment Systems, Reuse Strategies and User Perception-a Review. Water Air Soil Pollut. 2018, 229, 255. [CrossRef] [PubMed]

17. Mandal, D.; Labhasetwar, P.; Dhone, S.; Dubey, A.S.; Shinde, G.; Wate, S. Water conservation due to greywater treatment and reuse in urban setting with specific context to developing countries. Resour. Conserv. Recycl. 2011, 55, 356-361. [CrossRef]

18. Halalsheh, M.; Dalahmeh, S.; Sayed, M.; Suleiman, W.; Shareef, M.; Mansour, M.; Safi, M. Grey water characteristics and treatment options for rural areas in Jordan. Bioresour. Technol. 2008, 99, 6635-6641. [CrossRef]

19. Palmquist, H.; Hanaeus, J. Hazardous substances in separately collected grey- and blackwater from ordinary Swedish households. Sci. Total Environ. 2005, 348, 151-163. [CrossRef]

20. Eriksson, E.; Auffarth, K.; Henze, M.; Ledin, A. Characteristics of grey wastewater. Urb. Water 2002, 4, 85-104. [CrossRef]

21. Winward, G.P.; Avery, L.M.; Stephenson, T.; Jefferson, B. Essential oils for the disinfection of grey water. Water Res. 2008, 42, 2260-2268. [CrossRef]

22. Ramona, G.; Green, M.; Semiat, R.; Dosoretz, C. Low strength graywater characterization and treatmentby direct membrane filtration. Desalination 2004, 170, 241-250. [CrossRef]

23. Imnhof, B.; Muhlemann, J.; Morel, A. Greywater Treatment on Household Level in Developing Countries-A State of the Art Review. 2005. Available online: https://www.susana.org/en/knowledge-hub/resources-and-publications/library/details/1047 (accessed on 15 November 2021).

24. Zeeman, G.; Kujawa, K.; De Mes, T.; Hernandez, L.; De Graaff, M.; Abu-Ghunmi, L.; Mels, A.; Meulman, B.; Temmink, H.; Buisman, C.; et al. Anaerobic treatment as a core technology for energy, nutrients and water recovery from source-separated domestic waste (water). Water Sci. Technol. 2008, 57, 1207-1212. [CrossRef]

25. Sumisha, A.; Arthanareeswaran, G.; Thuyavan, Y.L.; Ismail, A.F.; Chakraborty, S. Treatment of laundry wastewater using polyethersulfone/polyvinylpyrollidone ultrafiltration membranes. Ecotoxicol. Environ. Saf. 2015, 121, 174-179. [CrossRef]

26. Travis, M.J.; Wiel-Shafran, A.; Weisbrod, N.; Adar, E.; Gross, A. Greywater reuse for irrigation: Effect on soil properties. Sci. Total Environ. 2010, 408, 2501-2508. [CrossRef]

27. Faulwetter, J.L.; Gagnon, V.; Sundberg, C.; Chazarenc, F.; Burr, M.D.; Brisson, J.; Camper, A.K.; Stein, O.R. Microbial processes influencing performance of treatment wetlands: A review. Ecol. Eng. 2009, 35, 987-1004. [CrossRef]

28. Pinto, U.; Maheshwari, B.L. Reuse of greywater for irrigation around homes in Australia: Understanding community views, issues and practices. Urb. Water J. 2010, 7, 141-153. [CrossRef]

29. Abu-Zreig, M.; Rudra, R.P.; Dickinson, W.T. Effect of Application of Surfactants on Hydraulic Properties of Soils. Biosyst. Eng. 2003, 84, 363-372. [CrossRef]

30. Jahin, H.S.; Abuzaid, A.S.; Abdellatif, A.D. Using multivariate analysis to develop irrigation water quality index for surface water in Kafr El-Sheikh Governorate, Egypt. Environ. Technol. Innov. 2020, 17, 100532. [CrossRef]

31. Asslouj, J.; Kholtei, S.; Amrani-Paaza, N.; Hilali, A. The impact of anthropogenic activities on the quality of groundwater of the Mzamza community (Chaouia, Morocco). Water Sci. 2007, 20, 309-321.

32. French Agency for Food, Environmental and Occupational Health \& Safety (ANSES), Analyse des Risques Sanitaires liés à la Réutilisation d'eaux Grises Pour des Usages Domestiques 2015. Available online: https://www.anses.fr/fr/system/files/EAUX2 011sa0112Ra.pdf (accessed on 15 November 2021).

33. Ottosona, J.; Stenstr, T.A. Faecal contamination of greywater and associated microbial risks. Water Res. 2003, 37, 645-655. [CrossRef]

34. Ahmed, W.; Gardner, T.; Toze, S. Microbiological quality of roof-harvested rainwater and health risks: A review. J. Environ. Qual. 2011, 40, 13-21. [CrossRef]

35. World Health Organization (WHO). Excreta and Greywater use in agriculture. In Guidelines for the Safe Use of Wastewater, Excreta and Greywater; WHO: Geneva, Switzerland, 2006. 
36. Lu, R.; Zhao, X.; Li, J.; Niu, P.; Yang, B.; Wu, H.; Wang, W.; Song, H.; Huang, B.; Zhu, N.; et al. Genomic characterisation and epidemiology of 2019 novel coronavirus: Implications for virus origins and receptor binding. Lancet 2020, 395, 565-574. [CrossRef]

37. Zhou, P.; Yang, X.L.; Wang, X.G.; Hu, B.; Zhang, L.; Zhang, W.; Si, H.R.; Zhu, Y.; Li, B.; Huang, C.L.; et al. A pneumonia outbreak associated with a new coronavirus of probable bat origin. Nature 2020, 579, 270-273. [CrossRef]

38. McKinney, K.R.; Gong, Y.Y.; Lewis, T.G. Environmental Transmission of SARS at Amoy Gardens. J. Environ. Health 2006, 86, 26.

39. Yu, I.T.; Li, Y.; Wong, T.W.; Tam, W.; Chan, A.T.; Lee, J.H.; Leung, D.Y.; Ho, T. Evidence of Airborne Transmission of the Severe Acute Respiratory Syndrome Virus. N. Engl. J. Med. 2004, 350, 1731-1739. [CrossRef] [PubMed]

40. Liu, L.; Lopez, E.; Dueñas-Osorio, L.; Stadler, L.; Xie, Y.; Alvarez, P.J.; Li, Q. The importance of system configuration for distributed direct potable water reuse. Nat. Sustain. 2020, 3, 548-555. [CrossRef]

41. Williams, E.; Isles, N.; Chong, B.; Bond, K.; Yoga, Y.; Druce, J.; Catton, M.; Ballard, S.A.; Howden, B.P.; Williamson, D.A. Detection of SARS-CoV-2 in saliva: Implications for specimen transport and storage. J. Med. Microbiol. 2021, 70, 001285. [CrossRef]

42. Sun, J.; Zhu, A.; Li, H.; Zheng, K.; Zhuang, Z.; Chen, Z.; Shi, Y.; Zhang, Z.; Chen, S.B.; Liu, X.; et al. Isolation of infectious SARS-CoV-2 from urine of a COVID-19 patient. Emerg. Microbes Infect. 2020, 9, 991-993. [CrossRef]

43. Danchin, A.; Ng, T.W.; Turinici, G. A New Transmission Route for the Propagation of the SARS-CoV-2 Coronavirus. Biology 2020 10, 10. [CrossRef]

44. Xiao, F.; Tang, M.; Zheng, X.; Liu, Y.; Li, X.; Shan, H. Evidence for Gastrointestinal Infection of SARS-CoV-2. Gastroenterology 2020, 158, 1831-1833. [CrossRef]

45. Wu, F.; Zhang, J.; Xiao, A.; Gu, X.; Lee, W.L.; Armas, F.; Alm, E.J. SARS-CoV-2 titers in wastewater are higher than expected from clinically confirmed cases. Appl. Environ. Sci. 2020, 5, e00614-20. [CrossRef]

46. Mallapaty, S. How Sewage Could Reveal True Scale of Coronavirus Outbreak. Nature 2020, 580, 176-177. [CrossRef] [PubMed]

47. Bar-Or, I.; Weil, M.; Indenbaum, V.; Bucris, E.; Bar-Ilan, D.; Elul, M.; Levi, N.; Aguvaev, I.; Cohen, Z.; Shirazi, R.; et al. Detection of SARS-CoV-2 variants by genomic analysis of wastewater samples in Israel. Sci. Total Environ. 2021, 789, 148002. [CrossRef] [PubMed]

48. Akhtar, P.; Ahmed, Y.; Islam, F.; Alam, K.; Mary, M.; Islam, M.Z.; Bhuiyan, M.M.H.; Yaakob, Z. Efficiency of Effluent Treatment Plants and Threat to Human Health and Aquatic Environment in Bangladesh. Asian J. Chem. 2016, 28, 60-68. [CrossRef]

49. Ensink, J.H.; Van Der Hoek, W.; Matsuno, Y.; Munir, S.; Aslam, M.R. Use of Untreated Wastewater in Peri-Urban Agriculture in Pakistan: Risks and Opportunities; International Water Management Institute: Colombo, Sri Lanka, 2002; Available online: http: //www.iwmi.cgiar.org/Publications/IWMI_Research_Reports/PDF/pub064/Report64.pdf (accessed on 20 November 2021).

50. Qishlaqi, A.; Moore, F.; Forghani, G. Impact of untreated wastewater irrigation on soils and crops in Shiraz suburban area, SW Iran. Environ. Monit. Assess. 2008, 141, 257-273. [CrossRef]

51. World Health Organization. 2019-nCoV Outbreak Is an Emergency of International Concern; World Health Organization: Geneva, Switzerland, 2020.

52. Boano, F.; Caruso, A.; Costamagna, E.; Ridolfi, L.; Fiore, S.; Demichelis, F.; Galvão, A.; Pisoeiro, J.; Rizzo, A.; Masi, F. A review of nature-based solutions for greywater treatment: Applications, hydraulic design, and environmental benefits. Sci. Total Environ. 2020, 711, 134731. [CrossRef]

53. Li, F.; Behrendt, J.; Wichmann, K.; Otterpohl, R. Resources and nutrients oriented greywater treatment for non-potable reuses Water Sci. Technol. 2008, 57, 1901-1907. [CrossRef] [PubMed]

54. Barsan, N.; Joita, I.; Stanila, M.; Radu, C.; Dascalu, M. Modelling wastewater treatment process in a small plant using a sequencing batch reactor (SBR). Environ. Eng. Manag. J. 2014, 13, 1561-1566. [CrossRef]

55. Barsan, N.; Nedeff, V.; Temea, A.; Mosnegutu, E.; Chitimus, A.D.; Tomozei, C. A Perspective for Poor Wastewater Infrastructure Regions: A Small-Scale Sequencing Batch Reactor Treatment System. Chem. J. Mold. 2017, 12, 61-66. [CrossRef]

56. Hourlier, F.; Masse, A.; Jaouen, P.; Lakel, A.; Gerente, C.; Faur, C.; Cloirec, P.L. Membrane process treatment for greywater recycling: Investigations on direct tubular nanofiltration. Water Sci. Technol. 2010, 62, 1544-1550. [CrossRef]

57. Gual, M.; Moià, A.; March, J.G. Monitoring of an indoor pilot plant for osmosis rejection and greywater reuse to flush toilets in a hotel. Desalination 2008, 219, 81-88. [CrossRef]

58. Itayama, T.; Kiji, M.; Suetsugu, A.; Tanaka, N.; Saito, T.; Iwami, N.; Mizuochi, M.; Inamori, Y. On site experiments of the slanted soil treatment systems for domestic gray water. Water Sci. Technol. 2006, 53, 193-201. [CrossRef]

59. Dalahmeh, S.S.; Pell, M.; Vinnerås, B.; Hylander, L.D.; Öborn, I.; Jönsson, H. Efficiency of Bark, Activated Charcoal, Foam and Sand Filters in Reducing Pollutants from Greywater. Water Air Soil Pollut. 2012, 223, 3657-3671. [CrossRef]

60. Brewer, D.; Brown, R.; Stanfield, G. Rainwater and Greywater in Buildings: Project Report and Case Studies; Building Services 2001. Available online: https://www.waterwise.org.uk/wp-content/uploads/2018/02/Brewer-et-al.-2001_Rainwater-andGreywater-in-Buildings_Project-and-Case-Studies.pdf (accessed on 20 November 2021).

61. Pidou, M.; Avery, L.; Stephenson, T.; Jeffrey, P.; Parsons, S.A.; Liu, S.; Memon, F.A.; Jefferson, B. Chemical solutions for greywater recycling. Chemosphere 2008, 71, 147-155. [CrossRef]

62. Diaper, C.; Dixon, A.; Butler, D.; Fewkes, A.; Parsons, S.A.; Strathern, M.; Stephenson, T.; Strutt, J. Small scale water recycling systems-Risk assessment and modelling. Water Sci. Technol. 2001, 43, 83-90. [CrossRef] [PubMed]

63. Kariuki, F.W.; Ngàngà, V.G.; Kotut, K. Hydrochemical Characteristics, Plant Nutrients and Metals in Household Greywater and Soils in Homa Bay Town. Open Environ. Eng. J. 2012, 5, 103-109. [CrossRef] 
64. Šostar-Turk, S.; Petrinić, I.; Simonič, M. Laundry wastewater treatment using coagulation and membrane filtration. Resour. Conserv. Recycl. 2005, 44, 185-196. [CrossRef]

65. Pearce, G. Introduction to membranes: Fouling control. Filtr. Sep. 2007, 44, 30-32. [CrossRef]

66. Lin, C.J.; Lo, S.L.; Kuo, C.Y.; Wu, C.H. Pilot-Scale Electrocoagulation with Bipolar Aluminum Electrodes for On-Site Domestic Greywater Reuse. J. Environ. Eng. 2005, 131, 491. [CrossRef]

67. Bani-Melhem, K.; Smith, E. Grey water treatment by a continuous process of an electrocoagulation unit and a submerged membrane bioreactor system. Chem. Eng. J. 2012, 198, 201-210. [CrossRef]

68. Parsons, S.A.; Bedel, C.; Jefferson, A.B. Chemical vs. Biological Treatment of Grey Water. In Chemical Water and Wastewater Treatment VI; Hahn, H.H., Hoffmann, E., Ødegaard, H., Eds.; Springer: Berlin, Germany, 2000.

69. Otterpohl, R.; Albold, A.; Oldenburg, A.M. Source control in urban sanitation and waste management: Ten systems with reuse of resources. Water Sci. Technol. 1999, 39, 153-160. [CrossRef]

70. Yeon, H.J.; Chang, D.; Kim, D.W.; Kim, B.K.; Choi, J.K.; Lim, S.Y.; Yoon, C.Y.; Son, D.J.; Kim, W.Y. Comparison of Attached Growth Process with Suspended Growth Process. World Acad. Sci. Eng. Technol. 2011, 60, 649-651.

71. Elmitwalli, T.A.; Shalabi, M.; Wendland, C.; Otterpohl, R. Grey water treatment in UASB reactor at ambient temperature. Water Sci. Technol. 2007, 55, 173-180. [CrossRef] [PubMed]

72. Lamine, M.; Bousselmi, L.; Ghrabi, A. Biological treatment of grey water using sequencing batch reactor. Desalination 2007, 215, 127-132. [CrossRef]

73. Gross, A.; Shmueli, O.; Ronen, Z.; Raveh, E. Recycled vertical flow constructed wetland (RVFCW)—A novel method of recycling greywater for irrigation in small communities and households. Chemosphere 2007, 66, 916-923. [CrossRef]

74. Dallas, S.; Scheffe, B.; Ho, G. Reedbeds for greywater treatment-Case study in Santa Elena-Monteverde, Costa Rica, Central America. Ecol. Eng. 2004, 23, 55-61. [CrossRef]

75. Publications Office of the European Union. Procédés Extensifs d'épuration des Eaux Usées Adaptés aux Petites et Moyennes Collectivités (500-5000 eq-hab). 2003. Available online: https:/ / op.europa.eu/en/publication-detail/-/publication/a08310d9-8 3d8-48dd-98fe-25c80b4dc4c2/language-fr/format-RDF (accessed on 20 November 2021).

76. Hocaoglu, S.M.; Atasoy, E.; Baban, A.; Orhon, D. Modeling biodegradation characteristics of grey water in membrane bioreactor. J. Membr. Sci. 2013, 429, 139-146. [CrossRef]

77. Friedler, E.; Kovalio, R.; Ben-Zvi, A. Comparative study of the microbial quality of greywater treated by three on-site treatment systems. Environ. Technol. 2006, 27, 653-663. [CrossRef] [PubMed]

78. Ayers, R.S.; Westcot, D.W. Water Quality for Agriculture; Food and Agriculture Organization of the United Nations: Rome, Italy, 1985 .

79. Jabri, K.M.; Fiedler, T.; Saidi, A.; Nolde, E.; Ogurek, M.; Geissen, S.U.; Bousselmi, L. Steady-state modeling of the biodegradation performance of a multistage moving bed biofilm reactor (MBBR) used for on-site greywater treatment. Environ. Sci. Pollut. Res. Int. 2019, 26, 19047-19062. [CrossRef]

80. Chaabane, S.; Riahi, K.; Hamrouni, H.; Thayer, B.B. Suitability assessment of grey water quality treated with an upflow-downflow siliceous sand/marble waste filtration system for agricultural and industrial purposes. Environ. Sci. Pollut. Res. Int. 2017, 24, 9870-9885. [CrossRef] 